\title{
二回線直流送電線路の高精度等価回路の一考察
}

\author{
正員 猪 野 朋 敦 (神奈川大) \\ 名誉員 上之園 親 佐 (京 都大)
}

\section{An Examination of Highly Accurate Equivalent Circuit for Double-Circuits DC Transmission Lines}

Tomoatsu Ino, Member (Kanagawa University), Chikasa Uenosono, Honorary Member (Kyoto University, Professor Emeritus)

It is pointed out that frequency dependent effects of some elements of transformation matrix of double circuits transmission line constructed by current eigen-vector formings contradict physical causal relationship. This contradiction may be a substantial factor of error for any expression of a transient program in modal frame.

This paper presents a technique to remove the contradiction and to stabilize the characteristics in low frequency by means of modification of line constant. The technique is effective for double circuits DC transmission lines with neutral lines and make the apporoximation process by low order transfer function simple.

Effect of the modification is included in equivalent circuits composed of integrated resistance accounted at low frequency and modified distributive line. The transient behaviour of the equivalent circuits are closely similar to these of Fourier tranformation.

キーワード : 送電線路, 不平衡, 過渡現象, 等価回路

\section{1. まえがき}

表皮効果および大地の影響を考虑した不平衡二回線架空 送電線路の過渡現象解析にモード域ベルジェロン法 ${ }^{(1)}$ 適用し，モード域周波数低存特性（モード伝搬特性，変換 行列およびサージアドミタンス）を低次伝達関数で近似す る場合，変撸行列拉よびサージアドミタンスの実部ならび に虚部の周波数依存特性と近似特性を一致させるために は，一部要素の伝達関数の根を不安定とする必要のあるこ とが知られている(2)。著者らは現状の固有べクトル規格化 手法(1)(2)(7) を用いて二回線直流扔よび交流線路のモード変 換行列系の周波数依存特性を詳細に検討した結果，前記に 加えて更に周波数の変化に対する実部および虚部の局部的 挙動が因果律を満足しない場合のあることを見いだした。

これらの結果は不平衡線路へのモード域ベルジェロン法 の適用精度が, 線路構成, 対象とする周波数範囲あるいは 解析時間に依存することを示している。

一方, 相領域ベルジェロン (3) 法では上記の問題は観測 されて扔らず(4)，この点で有利であると考えられるが，相 領域伝搬特性はモード領域伝搬特性の荷重和となることか ら, 近似が複雑となる。従って, 妥当な線路定数の変更で
安定な周波数依存特性が得られ，かつ線路定数変更の精度 への影響が等価回路で吸収できれば, モード領域解析法は この点で有利となる。

著者らは二回線直流線路(5)で, 線路定数から極低周波 に扔ける抵抗成分を除去した変更線路定数を用いてモード 解析を実施した結果, 变換行列系の周波数依存特性は因果 律を満足し, かつ安定となり, また除去した抵抗成分に相 当する集中抵抗と上記の変換行列系を用いて構成した分布 線路からなる等価回路の過渡現象解析結果は, フーリ工解 析による解とよく一致することを見いだした。上記の結果 は, 変換器の制御を含む直流系統の過渡現象の解析など, 低周波域の周波数依存特性をも取り込む必要のある中性線 方式二回線直流線路の高精度モデルの作成に有益である。

\section{2. 二回線架空線路の周波数依存特性と炎の インパルス応答の性質}

不平衡線路のモード域周波数依存特性は, モード電流ま たは電圧変換行列，モードサージアドミタンス拉よびモー ド伝搬特性の各周波数依存特性により表される。モード域 ベルジェロン法による数值解析モデルが作成できるために は，これら周波数依存特性が，少なくとも現在までの入力 
と過去の応答から現在の応答を決定できる性質,すなわち 因果律を満足する必要がある。この条件を満足するか否か は周波数依存特性の実部の挙動のみならず虚部の挙動にも 同等に依存する。従来のモード域における取扱いでは, 変 換行列系（モードサージアドミタンスを含む）の周波数依 存特性が前記条件を满足するものとし, 従って実部特性の みで近似できるとしている(6)。しかし, 現状の固有べクト ル構成法(1)(2)(7)によれば，この条件は必ずしも成立するも のではない。

以下, $\langle 2 \cdot 1\rangle$ 節では変換行列系の性質について述べ, $<2 ・$ $2\rangle$ 節ではく2・1〉節で引き出された変換行列の性質に関する 幾つかの疑義について検討する。

〈2・1〉 変換行列系の性質 解析したモデル線路の導 体配置を図 1 に示した。(a)図および(b)図はそれぞれ新 山口幹線（電源開発）を参考とした $500 \mathrm{kV}$ 級二回線交流 線路抢よび士 $650 \mathrm{kV}$ 級の中性線付き二回線直流線路 ${ }^{(5)}$ で ある。図 2 は前記モデル線路について, サージアドミタン スを単位実定数と置く固有べクトル規格化法(7)による変 換行列の周波数依存特性を示している。フーリ工変換の知 識から, 図 2(a)で示す $[3,2]$ 要素は $10 \mathrm{~Hz}$ から $100 \mathrm{kHz}$ 付近での実部の変化に虚部の極性が対応していないこと, また, 〔1,5]要素では $100 \mathrm{~Hz}$ 付近の実部の変化に虚部の
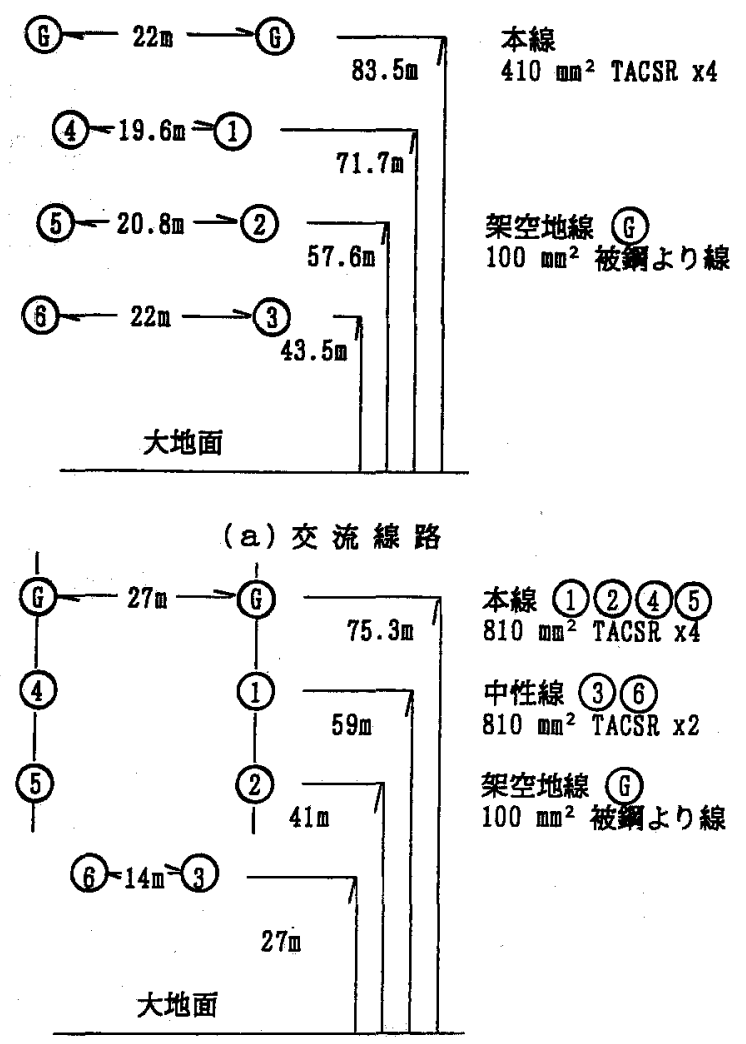

（b）直流線路

図 1 モデル二回線線路の導体配置

Fig. 1. Spacing of line conductors and other dimensions of model double circuits transmission lines.
変化が伴わないため，これら要素は因果律を満足しないこ とが予想される。同样の状態は (b)図に示す直流線路 $[3,5]$ 要素の $0.1 \mathrm{~Hz}$ から $5 \mathrm{~Hz}$ 付近でも観測される。これ を陽に示すためにはフーリエ解析を行えばよい。

$$
\begin{aligned}
& T_{i j}(\omega)=\Sigma\left\{K_{m} /\left(1+j \omega T_{d m}\right)\right\}+C \\
& T_{i j}(\omega)=G(\omega)+C_{0} \cdots \cdots \cdots \cdots \cdots \cdots \cdots \cdots \cdots \cdots \cdots
\end{aligned}
$$

いま，周波数特性が $(1 \mathrm{a})$ 式で近似できるものとすると， そのインパルス応答は同程度の直流利得 $\left(K_{m}\right)$ をも項の うち, 時定数 $\left(T_{d m}\right)$ の大きい項は小さい項に埋もれる。 従って, 目的とする周波数領域でのインパルス応答の性質 を調べるためには，(1b)式の $G(\omega)$ が上限周波数付近で 十分減衰するよう定数 $C_{0}$ を選んだ後, 更に $G(\omega)$ につい て空関数 $\delta\left(\omega_{0}\right)$ を掛けて上限周波数 $\left(\omega_{0}\right)$ 以上を十分減衰 させ,フーリエ解析を実施すればよい。

図3(a)，(b)は，それぞれ，図2(a)に示した交流線 路の場合の $(3,2)$ よび $[1,5]$ 要素のインパルス応答を示し
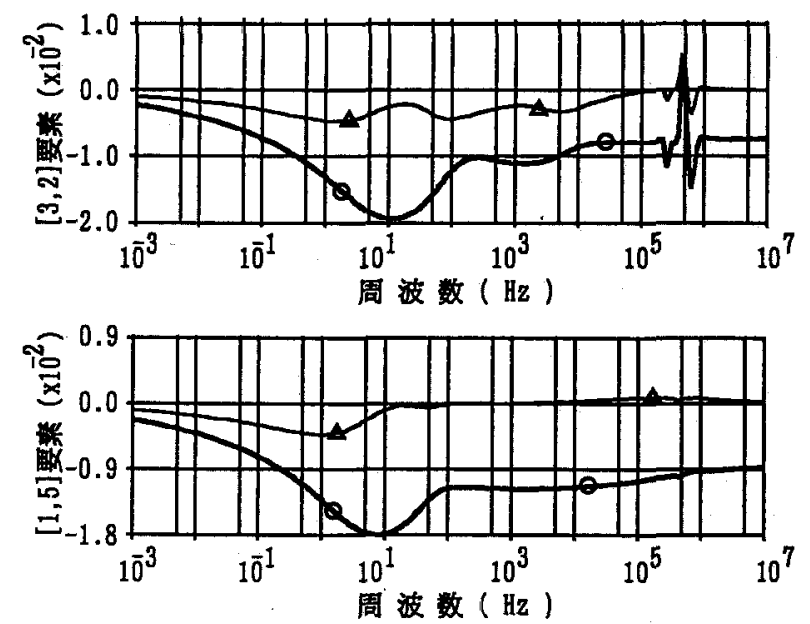

（a）交流線路の坸合

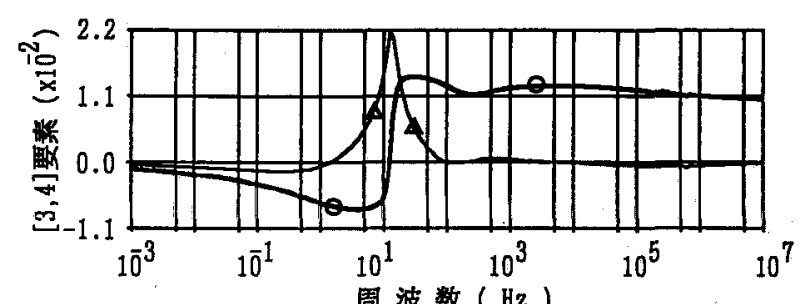

周波数( $\mathrm{Hz})$

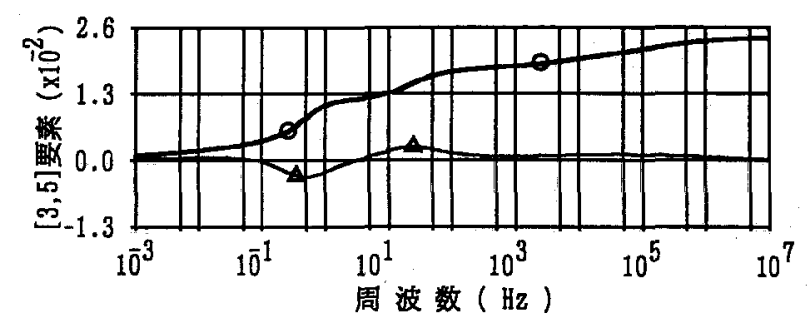

（b）直流線路の埸合

実部 一O- - 、 、虚部 $-\Delta-\Delta-$

図 2 変換行列の周波数依存特性

Fig. 2. Frequency dependent effects of transformation matrix. 
ている。これらのフーリエ解析で評洒した周波数は $[3,2]$ 要素で $100 \mathrm{kHz}$ 以下であり，〔1,5]要素で $1 \mathrm{kHz}$ 以下で ある。図中で上段は正の，下段は負の時間に対する応答を 示しており，〔3，2]要素では負の時間に対する応答が支配 的である。また，〔1,5]要素では正および負の時間に対す る応答は同等となっている。これらの結果は変換行列の要 素の一部は明らかに因果律に違反し, 従って, 変換行列系 の周波数依存特性を数值モデル化する際の本質的な誤差要 因となることを示している。この問題は他のモードでも観 測されるが，図2(a)に示したように交流線路の場合には $10 \mathrm{kHz}$ 付近と比較的高い周波数でも観測されるのに比 べ（（b)図に示したように直流線路では比較的低周波域て 観測される。

なお，以上と同様の事態は固有ベクトルの要素の一つを

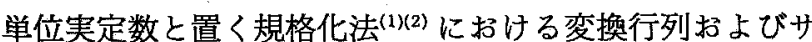
ージアドミタンスでも観測される。

〈2・2〉 変換行列系の性質に関する検討 前節の結果 は，（1）固有べクトルに数値不安定が発生し他の要素との 識別が不可となる，いわゆるモードクロスの発生に起因す るのではないか，また，(2)相領域（物理系）で因果律が 満足される以上，変換行列系も自律的に因果律を満足する のではないかとの疑義が生ずる。これらを単純な線路で検
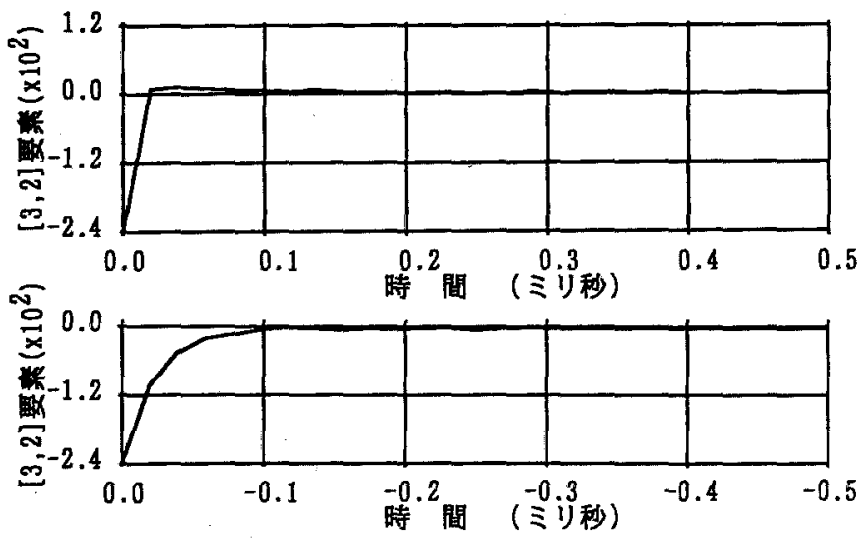

(a) $(3,2)$ 要素の応答
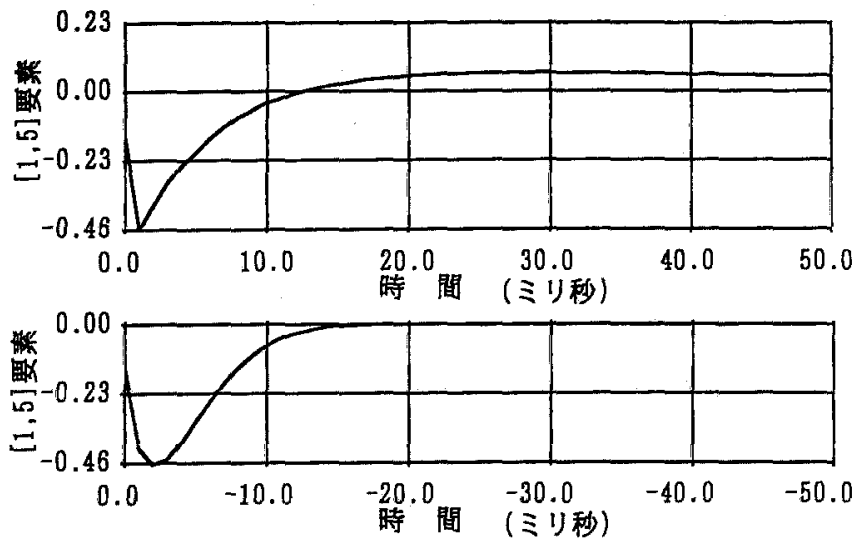

(b) $(1,5)$ 要素の応答

図 3 変換行列要素のインパルス応答 Fig. 3. Impulse responce of elements of transformation matrix.
討するため，図 1(a)の導体配㯰から架空地線および第 2 および第 5 の導体を除去した二相二回線線路を取り上げ る。この構成の線路では第 1 回線と第 2 回線は対称である から，実定数変換行列により互いに相互結合のない第 1 回 路および第 2 回路に分離でき(4)，個々の回路で取り报う毛 ード数は 2 個となる。

図 4 は前記第 2 回路の変換行列系に関し, 固有ベクトル の要素の一つを単位実定数と置いた場合の変換行列わよび サージアドミタンスを示している。前節の議論から，変換 行列要素 $[2,1]$ おるび $[1,2]$ ，ならびに第 1 および第 2 モー ドサージアドミタンスは 10〜 $100 \mathrm{~Hz}$ 付近で明らかに因果 律を満足しない。一方, 変換行列の第 1 列と第 2 列は明ら かに互いに独立，分離されて扣り，これらモード量から第 2 回路線路アドミタンスとインピーダンスの積を逆構成し た場合の誤差は $10^{-12}$ 程度以下である。従って，疑問 (1) のモードクロスは発生していないといえる。また，モード 量の周波数連続化手法として本論文で使用した固有べクト
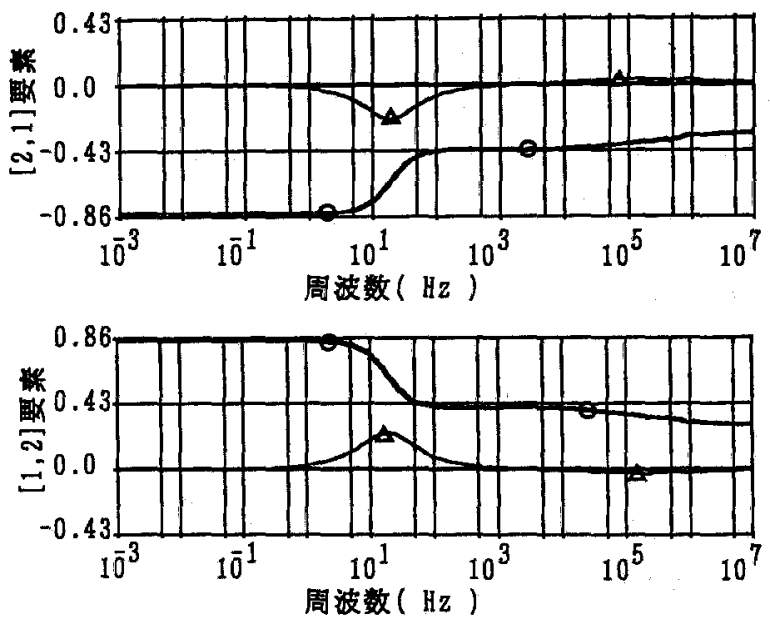

（a）モート変换行列（電流）
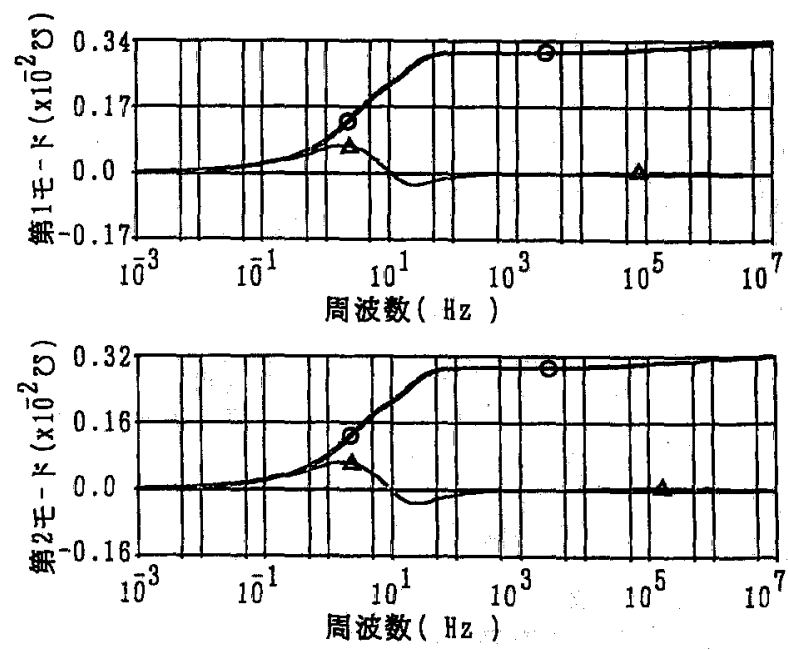

(b) モードサージアドミタンス

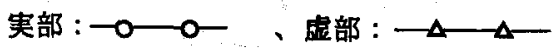

図 4 変換行列系の周波数依存特性

Fig. 4. Frequency dependent effects of transformation matrix and surge admittance. 


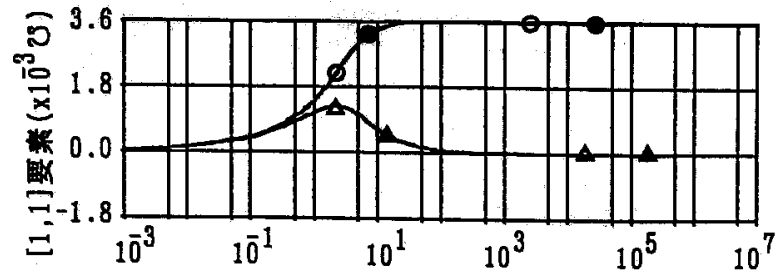

周波数( $\mathrm{Hz})$

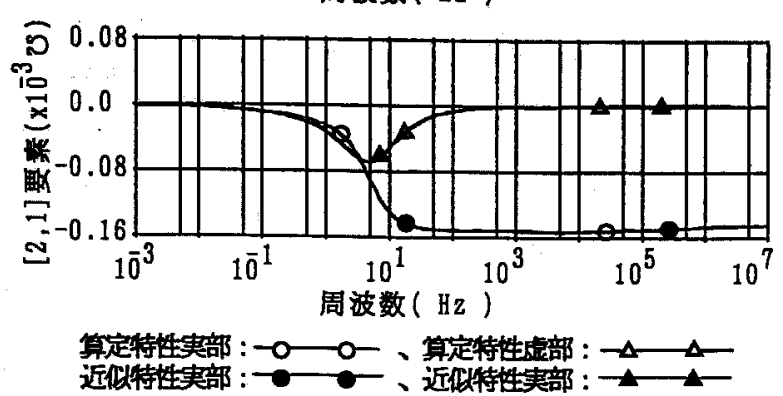

図 5 相サージアドミタンスとその近似周波数 依存特性

Fig. 5. Frequency dependent effects of the phasesurge admittance and it's approximation.

ル追跡法は，モードクロスの発生を十分抑制している。 次に, 疑問 (2)に関し, 第 2 回路相サージアドミタンス $\left(Y_{2 p s}\right)$ と第 2 回路変換行列 $\left(T_{2 c}\right)$ およびモードサージアド ミタンス $\left(Y_{2 m s}\right)$ の関係は $(2)$ 式で与えられる。

$$
Y_{2 p s}=T_{2 c} Y_{2 m s} T_{2 c}^{t}
$$

ここで, 実際の相サージアドミタンスは第 1 および第 2 回 路相サージアドミタンスの実定数結合となるから，(2)式 左辺は準物理系であり，因果律を満足する必要がある。 (2) 式右辺の個々の変換行列およびモードサージアドミタ ンスが因果律を満足すれぱ，前記条件は明らかに満足され る。次に，図 4 に示した変換行列およびモードサージアド ミタンスを用いて,

$$
\begin{array}{r}
F(s)=k_{c}+\sum_{i} \frac{k_{i}}{1+s t_{d i}}+\sum_{j} \frac{k_{j} \zeta_{j} \omega_{n j} s}{s^{2}+\zeta_{j} \omega_{n j} s+\omega_{n j}^{2}} \\
t_{d i}>0, \quad 2>\zeta_{j}>0 \cdots \ldots \ldots \ldots \ldots \ldots
\end{array}
$$

(2)式により構成した第 2 回路相サージアドミタンスを図 5 に示した（図中の算定特性）。また同図に，(3)式の伝 達関数による周波数依存特性近似法(4)による近似結果を 示した。算定特性と近似特性はよく一致している。（3）式 の伝達関数は因果律を満足するから，従って，相サージア ドミタンスは因果律を満足しているといえる。以上から， モード変換行列系の因果律の充足は相領域系 (物理系) の 因果律の充足の必須条件ではないことが示された。もちろ ん, 固有べクトルは任意複素定数を含むから，因果律を満 足する変換行列系構成法の存在を否定するものではない が，現在，有効な方法は見いだされていない。

\section{3. 線路定数の変更による変換行列の周波数依存 特性の変化}

前章の解析から，直流線路では比較的低周波域で因果律
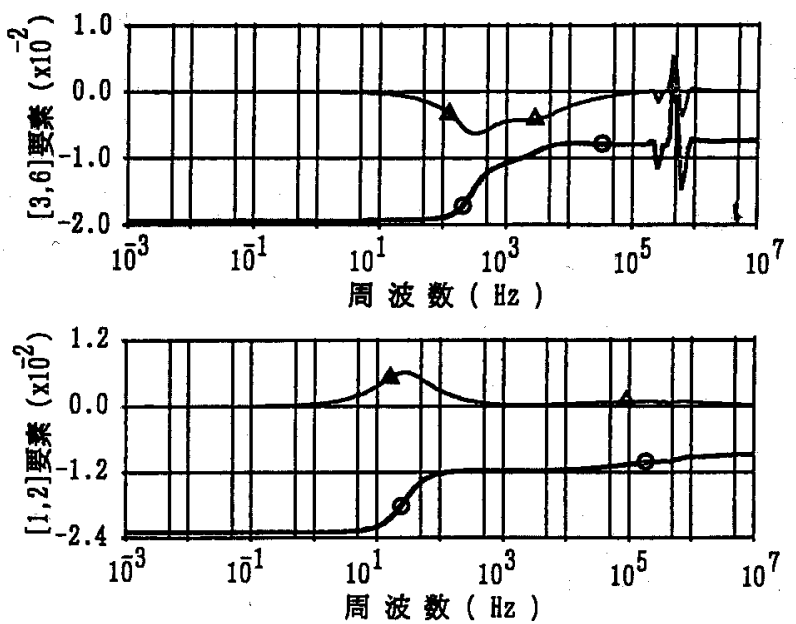

（a）交流線路の埸合
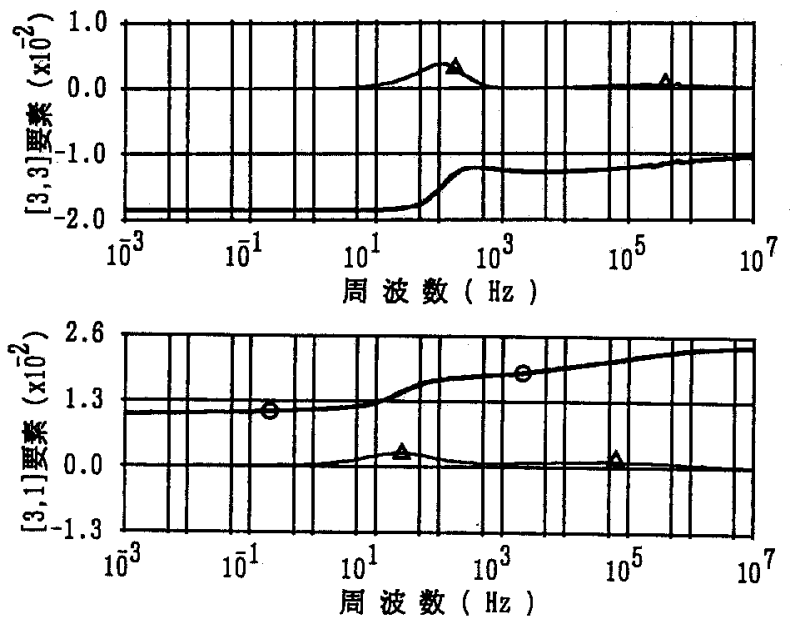

（b）直流線路の場合

実部 $-0-0-$ 、虚部 $-\Delta-\Delta-$

図 6 線路定数変更後の変換行列の周波数 依存特性

Fig. 6. Frequency dependent effects of transformation matrix with modified line constant.

違反が発生するため，交流線路に比べて長時間の過渡現象 解析に耐えられるモード域解析モデルが作成できる。しか し, 線路故障の発生から再起動に至る解析を実施するため には， 0.5 ないし 1 秒程度までの高精度の解析モデルが必 要となる。これを達成するためには，少なくとも 0.1 ない し $1 \mathrm{~Hz}$ 程度までの前記障害を取り除くことが望ましい。 低周波域（数十 $\mathrm{Hz}$ 以下）に扔けるこの障害は，元の線路 抵抗から直流抵抗值を差し引けば除去できることが数值実 験から見いだされた。

図 6(a)，（b)は図1(a)，（b )に示した構成の交流お よび直流線路で線路抵抗值から $0.001 \mathrm{~Hz}$ での抵抗值（表 皮効果および大地の影響を考慮して計算した線路抵抗は極 低周波数 $(0.1 \sim 0.001 \mathrm{~Hz})$ では直流抵抗に十分漸近し， 相互抵抗は自己成分に比べて無視できる程度となる）を差 し引いた抵抗值を用いた場合の変換行列の周波数依存特性 を示している。所属するモードは異なるが, 図中の各要素 

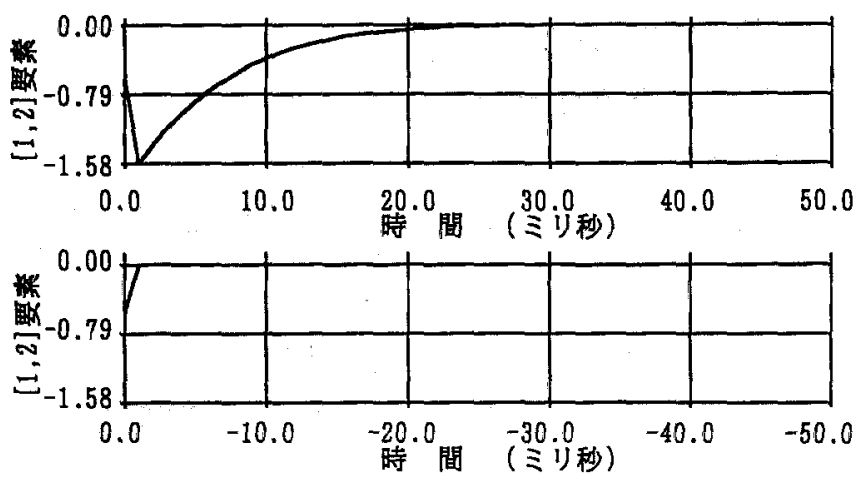

図 7 抵抗変更後の変換行列要素のインパルス応答

Fig. 7. Impulse responce of an element of transformation matrix with modified line resistance.

の周波数依存特性は, 高周波域で図 2 に示した線路抵抗変 更前の要素の特徴に類似している。この高周波域での類似 性はすべての要素で観測されるため, 線路抵抗の変化によ り変更前の要素が, 高周波域での周波数依存特性が類似な 変更後の要素に移行すると考えてよい。従って，交流線路 の場合, 図 2(a)の[1,5]要素は図 6(a)の $(1,2)$ 要素に移 行すると考えられ, $10 \mathrm{~Hz}$ 加ら $100 \mathrm{~Hz}$ 付近の比較的低周 波域で観測された因果律違反は解消している。これを陽に 示すため, 図 $7 に[1,2]$ 要素のフーリエ変換結果を示した。 明らかに負の時間に対する応答は無視できる。同様の結果 は直流線路でも観測され，図 2(b)の[3,5]要素で観測さ れた 0.1 から $5 \mathrm{~Hz}$ 付近での因果律違反は解消されている 〔図 6(b)の[3,1]要素参照〕。お恬，中性線方式 $500 \mathrm{kV}$ 級 および $800 \mathrm{kV}$ 級の二回線直流線路, 大地帰路方式二回線 線路についても，低周波域に扔ける因果律違反の解消に対 し同樣の結果を得ている。

直流二回線線路の場合, 変換行列系の因果律違反は比較 的低周波域で発生するため，この方法により解消できる が, 図6(a)の[3,6]要素で示すように, 交流二回線線路 の高周波域で発生する因果律違反は解消されない。従っ て，提案した方法はすべての二回線架空線路に適用できる ものではない。図 2 と図 6 の比較, 特に図 $2(b)$ の $(3,4]$ 要素と図 6(b)の $[3,3]$ 要素の比較から, 本章で述べた方 法は，また低周波域の周波数依存効果を安定化する。従つ て, 周波数依存特性を低次伝達関数で近似する場合(2), 近 似が容易となり，近似精度は向上する。この直流線路の例 では, 最大值に対する残留誤差の比は 0.01 から $100 \mathrm{kHz}$ の範囲で 4\%以下であった。

なお，以上の解析で使用した線路定数（抵抗，インダク タンスなど）の計算には $\mathrm{EMTP}^{(8)}$ を用いた。

\section{4. 等価回路とその精度の検討}

直流線路に対し，前章で得られた分布線路モデルおよび 除去した直流抵抗成分に相当する集中抵抗から等価回路が 構成できれば，因果律違反による誤差を回避した過渡現象 解析モデルが構成できる。従来, 分布線路の表現方法とし

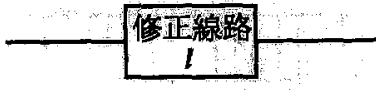

(a)偗正分布線路

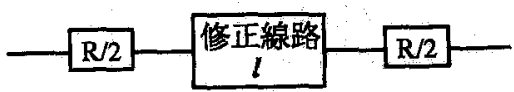

(b)等価回路 I

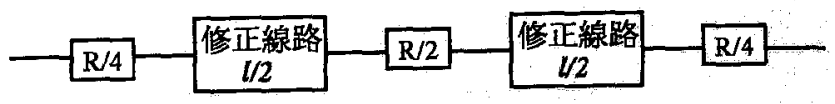

(c)等価回路 II

図 8 検討した等価回路

Fig. 8. Equivalent circuits for examination.

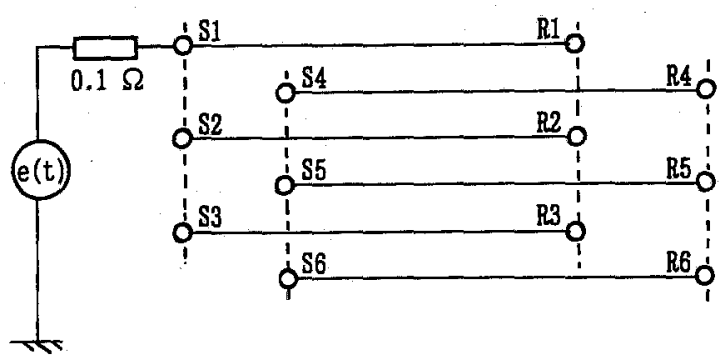

(a) 開故回路

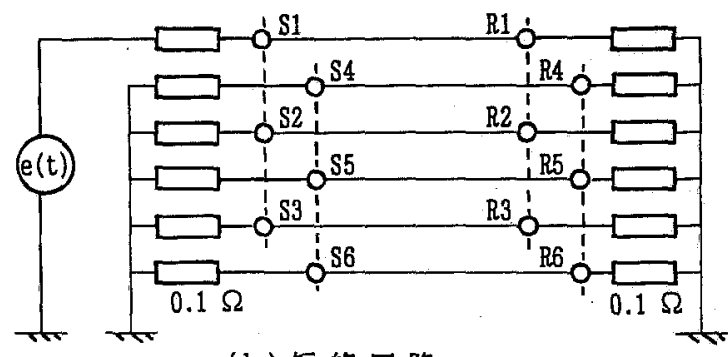

(b) 短絡回路

図 9 モデル回路

Fig. 9. Model circuits.

て, 無損失分布線路および集中抵抗からなる等価回路表現 がある(9)。この方法では線路抵抗の周波数依存特性を組み 込むことは困難である。しかし，この等価回路の無損失分 布線路を前章の分布線路に置き換えれば，前記周波数依存 性は組み込まれ，従って高精度の等価回路が期待できる。

上記の理由から，図 8 に示す等価回路を取り上げ検討し た。（b)図の等価回路 I は変更線路定数を用いて構成した 分布線路 (以後, 修正分布線路と呼ぶ) の両端に, 除去し た抵抗成分の $1 / 2$ に相当する抵抗を接続した回路であり，

(c) 図の等価回路 II は線路長 $(375 \mathrm{~km})$ を二分し, 而端 に $1 / 4$ ，中間に $1 / 2$ の抵抗を接続した回路である。また， （a 図は修正分布線路を示しており，精度の比較のため取 り上げた。

図 9 に試験を実施したモデル回路を示した。（a）図は電 圧応答の検討を主とした回路であり，電源端子を除き，す べて開放端である。開放端では両端に接続される抵抗成分 の効果はないから，等価回路に対し最も過酷な試験とな 
る。(b)図は電流応答の検討を主とした回路であり，電源 端子以外は接地端である。

前記 2 回路に対し，元の線路のフーリエ解析による時間 解と前述した修正分布線路, 等価回路 I およびIIにモード 域ベルジェロン法を適用したときの時間解を比較した。図 中の抵抗はプログラム作成上の便宜のためのものであり，

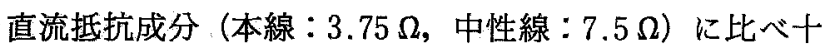
分小さい。なお，励振電圧波形恃空関数として周知であ $\eta, f_{0}$ 付近以下の周波数を同一のウエイトで評価できる下 記 (4) 式の時間関数および周期パルス（周期；1秒，デュ ティー比；50\%）の一部を用いた疑似ステップとした。

$$
\begin{array}{r}
e(t)=\sin \left\{2 \pi f_{0}\left(t-t_{0}\right)\right\} / 2 \pi f_{0}\left(t-t_{0}\right) \\
t_{0}=1 / 2 f_{0}, \quad\left(0<t<2 t_{0}\right)
\end{array}
$$

図 10(a)，(b) は図 9(a) 0回路で, 送電端第 1 相を(4) 式に示した電源で励振したときの, 受電端第 $1(R 1)$ 扔よ び第 5 相 $(R 5)$ の電圧波形を励振電圧のピーク值に対する
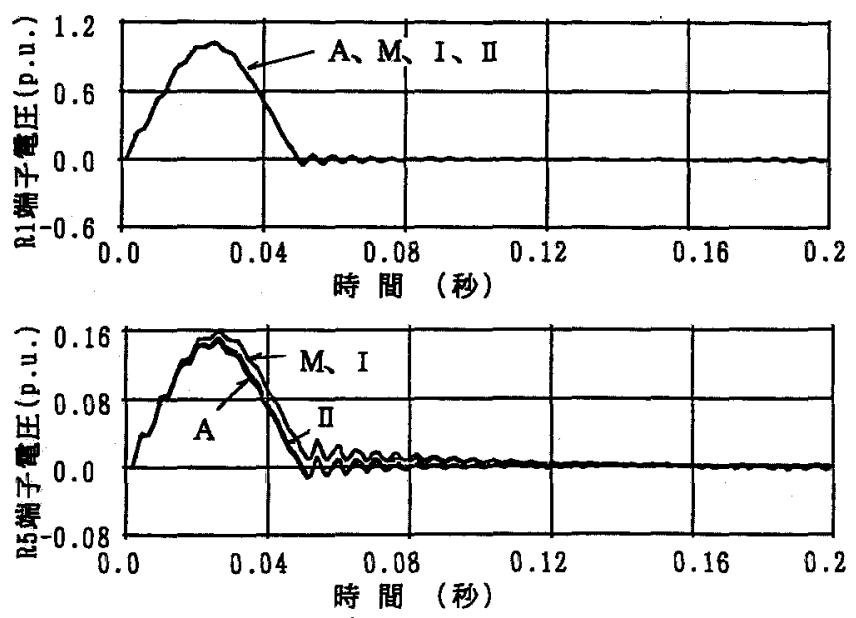

(a) $\mathrm{fo}_{\mathrm{o}}=20 \mathrm{~Hz}$
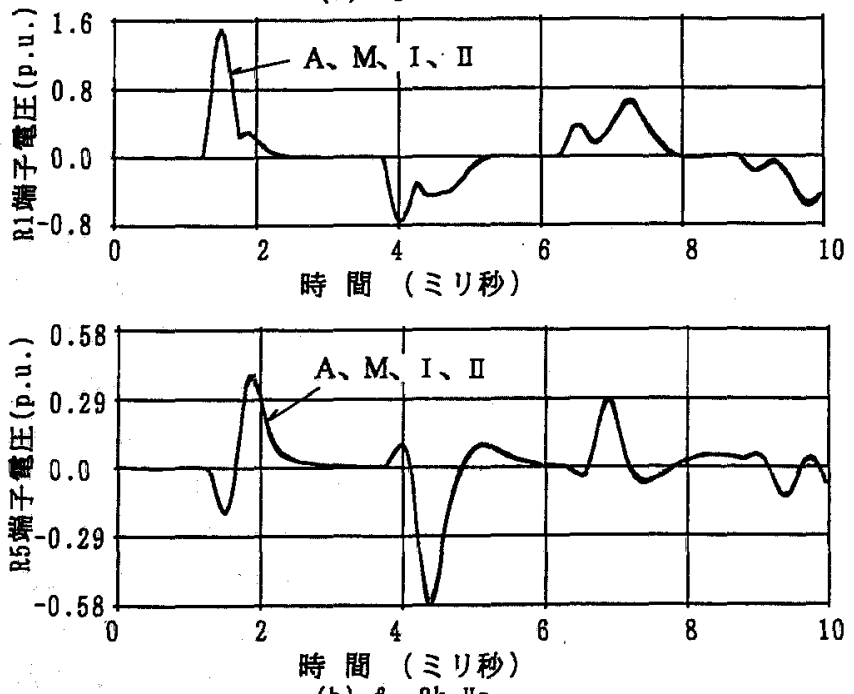

(b) $\mathrm{f}_{0}=2 \mathrm{kHz}$

図 10 フーリエ変換と等価回路による 電圧波形の比較

Fig. 10. Comparison among voltage wave shapes calculated with Fourier transformation and simulated with equivalent circuits $M, \mathrm{I}$ and II.
比で示している。図中の $A$ および $M, \mathrm{I} ， \mathrm{II}$ はそれぞれ フーリエ変換による厳密時間解扔よび修正分布線路，等価 回路 I, II の時間解を示している。(a) 図 $f_{0}=20 \mathrm{~Hz}$ の場 合, 励振相受電端（ $R 1$ 端子）の電圧波形は $M, \mathrm{I}, \mathrm{II}$ と もに厳密解 $A$ によく一致している。一方，被誘導相（R5 端子）の電圧波形では，等価回路Iによる解は厳密解とよ く一致するが，修正分布線路および等価回路 I による解に 悦相当の誤差が残る。(b)図 $f_{0}=2 \mathrm{kHz}$ の場合には励振 相，被誘導相に関わらず，修正分布線路，等価回路 I およ びIIの解は撖密解によく一致している。

図11(a)，(b) 㹥それぞれ，図 9(b)の回路で，送電 端第 1 相を $f_{0}=20 \mathrm{~Hz}$ および $2 \mathrm{kHz} て ゙$ 励振したときの受 電端第 $1(R 1)$ 预よび第 5 相 $(R 5)$ の電流波形を励振相送 電端（ $S 1$ 端子）への流入電流のピーク值に対する比で示 している。電圧波形の場合と同様に等価回路 II では励振 相, 被誘導相ともに厳密解とよく一致している。一方, 修 正分布線路の応答は $f_{0}=2 \mathrm{kHz}$ では良好であるが， $f_{0}=20$ $\mathrm{Hz}$ では大きな誤差を生成する。等価回路 I では $f_{0}=20$ $\mathrm{Hz}$ の場合の誘導電流に若干の誤差が発生している。

図 12 は図 9(a)の回路で送電端第 1 相に疑似ステップ 電圧を印加した場合の受電端第 1 相扔よび第 5 相の電圧波 形を示している。（a)図は（b)図に示す同一試験結果の時
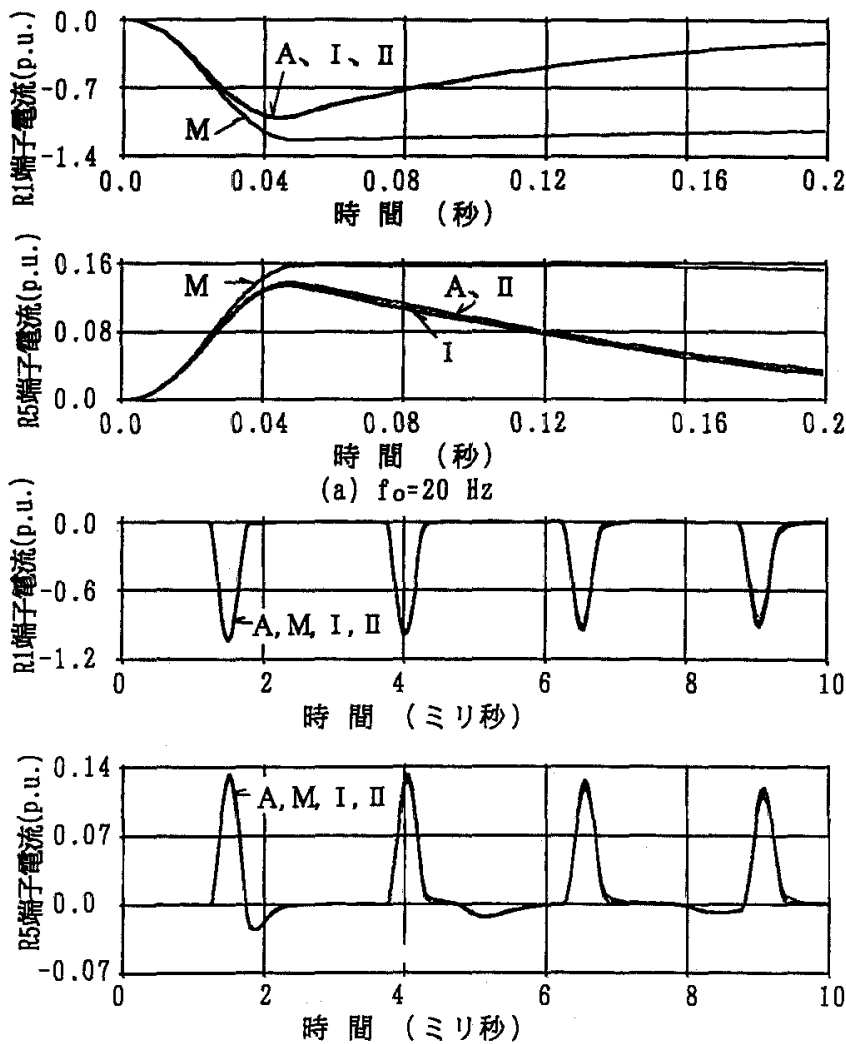

(b) $\mathrm{f}_{0}=2 \mathrm{k} \mathrm{Hz}$

図 11 フーリエ変換と等価回路による

電流波形の比較

Fig. 11. Comparison among current wave shapes calculated with Fourier transformation and simulated with the equivalent circuits $M$, I and II 

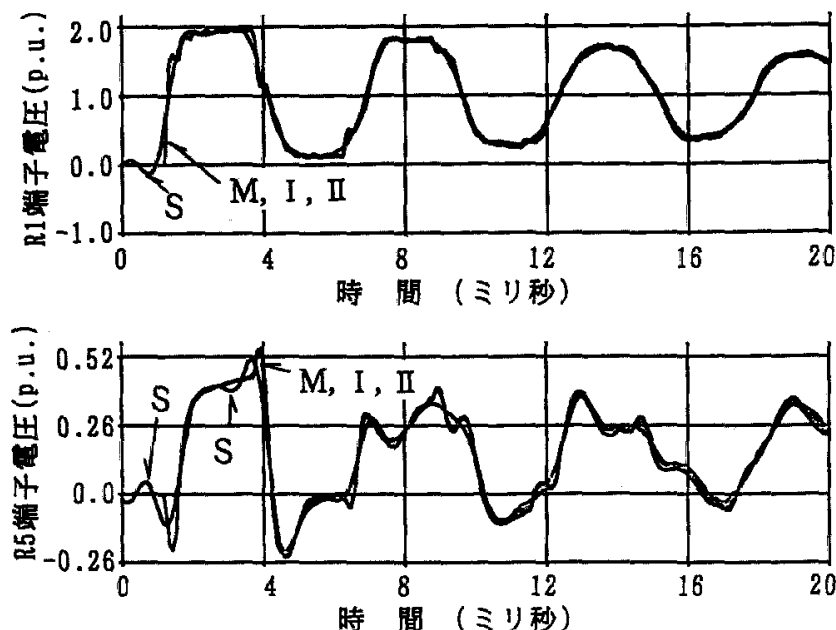

( $\mathrm{a})$
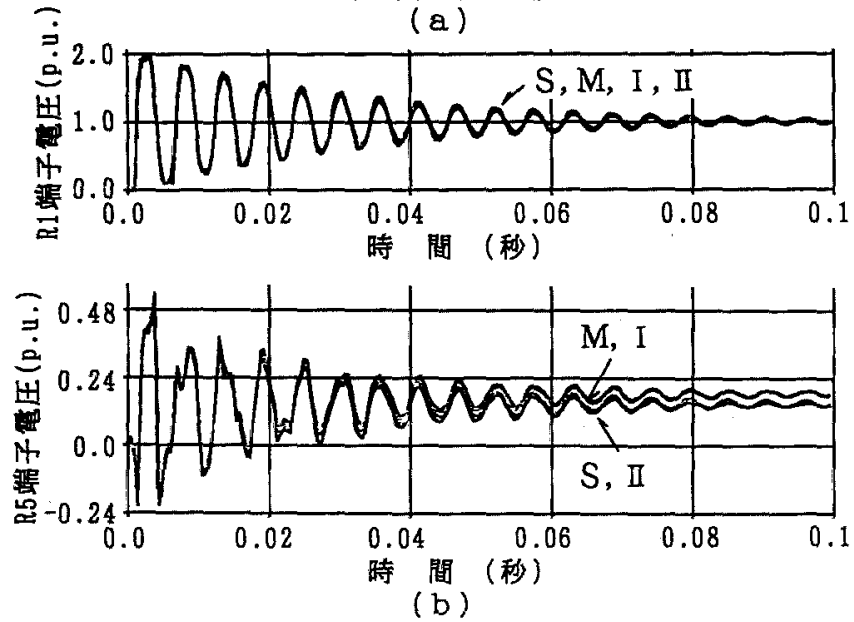

図 12 疑似ステップ電压に対する応答電圧波形

Fig. 12. The voltage responce wave shapes to the step voltage constructed by the edge part of cyclic pulse.
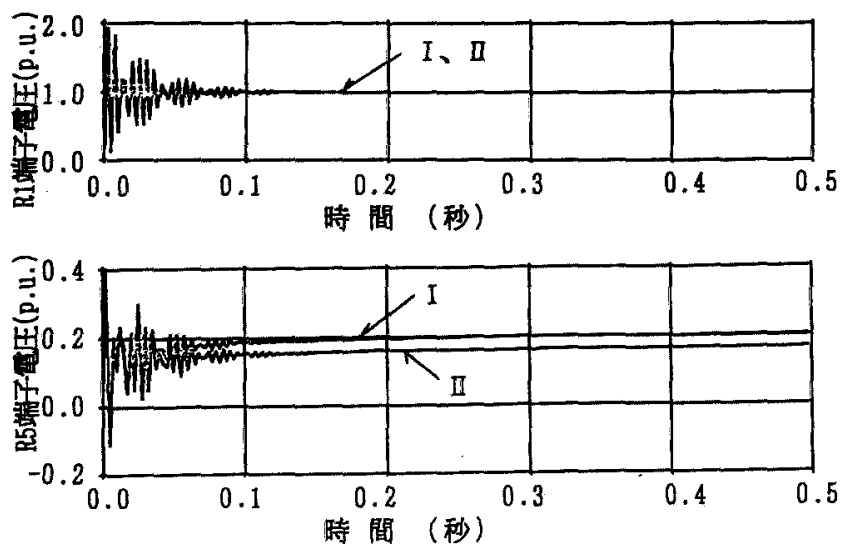

図 13 ステップ電圧に対する応答電圧波形

Fig. 13. The voltage wave shapes for the step responce.

間軸を拡大したものである。図中，S は元の分布線路の フーリエ解析結果を示しており， $M, \mathrm{I} お る ゙ \mathrm{II}$ お前記 記号と同じである。疑似ステップ電圧の構成に使用した周 波数は $3 \mathrm{kHz}$ 末満であり，従って，フーリエ解析結果に
は $3 \mathrm{kHz}$ 以上の元の分布線路の周波数特性は反映されな い。一方，同一疑似ステップ入力に対する等価回路の応答 には, $3 \mathrm{kHz}$ 以上の周波数成分が含まれる。以上を考慮 すれば，励振相受電端電圧波形 $[(\mathrm{a})$, (b) 図の $R 1$ 端子 電圧】は，元の分布線路のフーリ工解析結果，修正分布線 路, 等価回路 I およびII ともに, 相当よく一致していると いえる。一方, 被誘導相 ( ( a ), (b)図の $R 5$ 端子電圧]の 電圧波形では時間の経過とともに，フーリエ解析結果なら びに等価回路 II と修正分布線路ならぴに等価回路 I の応答 に相当の差粠が発生する。

次に, 等価回路 I およびIIの長時間解析に対する安定性 および定常值の精度を検証するため, 前述のモデル回路 (a)にステップ電圧を印加したときの応答を検討した。図 13 に受電端電圧波形を示している。同図から, 長時間解 析に扔ける安定性は十分であるといえる。また，検討した モデル回路では線路の線間および大地に対するコンダクタ ンスは考慮していないため, ステップ応答の最終值は静電 分圧で与えられる。等価回路II のステップ電圧印加後 0.5 秒時点の電圧と静電分圧值は, 線間距離最小の $R 2$ 端子で $0.26 \mathrm{pu}$ (静電分圧值 $0.24 \mathrm{pu}$ ), 最大の $R 6$ 端子で $0.13 \mathrm{pu}$ （静電分压值 $0.11 \mathrm{pu}$ ）となっており, 線路の不平衡に基 づく誘導電圧の差異をよく表現している。

以上の解析結果から，等価回路II は誘導をも含めて元の 周波数依存特性を精度良〈維持しているといえる。また， 修正分布線路は，その構成からの当然の㷌結であるが，低 周波域の応答に難点があり，等価回路 I では低周波域の誘 導に対する精度に難点が残るといえる。しかし，等価回路 I は励振相の応答に対する精度は十分であるから，励振相 の解析が主体となる場合，等価回路 II に比べて計算時間の 点で有利となる。

なおう，受電端第1相にステップ電圧を印加した場合の同 相受電端の最大過電圧注等価回路 I およびIIで $1.94 \mathrm{pu}$ あった。

\section{5. まとめ}

二回線架空線路の過渡現象解析にモード域ベルジェロン 法を適用する場合, 現状の固有べクトル構成法に基づく変 換行列系の一部は必ずしも因果律を満足するものではな く, 彷ってこれが変換行列系の周波数依存特性を表現する 場合の本質的な誤差要因となることを明らかにした。ま た, 中性線方式二回線直流線路における前記障害を除去す る方法について述べた。この方法に関し以下がいえる。

（1）線路抵抗から極低周波数での抵抗を除去すれば変 換行列系の周波数依存特性は因果律を満足する。

（2）周波数依存特性の低周波域の安定性が増し，近似 が容易となる。

（3）（1）に基づいて構成された等価回路II の解は厳密 解とよく一致する。

な扔, 二回線交流線路に括いては，モード領域の取扱い は変換行列系周波数依存特性の虚部の表現が困難であり， 
従って高精度の解析のためには, 相領域での解析が推迖さ れる。

終りに, 本論文が将来の長距離送電線路の解析の一助と なれば幸いである。

(平成 5 年 7 月 14 日受付, 同 5 年 12 月 13 日再受付)

$$
\text { 文献 }
$$

(1) L. Marti : "Simulation of transients in underground cables with frequency-dependent modal transformation matrices", IEEE Trans Power Delivery, 3, 1099 (1988)

（2）猪野:「二回線直流送電線路における周波数依存効果の高精度表 現法」, 䉓学論 B, 110, 395 (平 2-5)

(3) H. Nakanishi \& A. Ametani: "Transient calculation of a transmission line using superposition law", IEE Proc., 133, Pt. C, 263 (1986)

（4）猪野：「不平衡送電線路における周波数依存特性の一近似手法」, 電学論 $\mathrm{B}, 113,1446$ (平 5-12)

（5） UHV 送電特別委員会報告書 (昭 60-5)

(6) A. Dabuleanu \& A. Semlyen: "Modelling of transposition and double circuit transmission lines in switching surge calculation", IEEE Trans. Power Apparatus Syst., PAS-94, No.2, 242 (1975)

（7）猪野：「不平衡線路における周波数依存効果の新表現」, 電学論 B, 109,337 (平元-7)

(8) EMTP RULE BOOK, Bonneville Power Administration, April (1982)

(9) H.W. Dommel : "Digital Computer Solution of Electromagnetic Transient in Single and Multi phase Networks", IEEE Trans. Power Apparatus Syst., PAS-88, No. 4, 388 (1969)
猪 野朋 敦 (正員) 1943 年 7 月 8 日生。1968 年 3 月神奈川

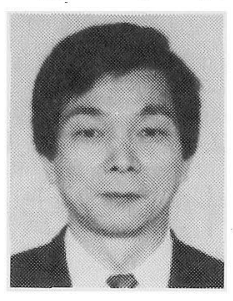
大学工学部電気工学科卒業。1 1970 年 3 月同大学 大学院電気工学専攻修士課程修了同年 4 月同大 学電気工学科勤務，現在に至る。この間，1982 年 7 月より 1 年間カナダ・マニトバ大学電気工学 科およびマニトバ HVDC 研究センターに在籍。 主として, 交直連係系統の制御保護の研究に従 事。

上之園 親 佐 （名誉員）1919 年 3 月 27 日生。1943 年 9 月京 都帝国大学工学部電気工学科卒業。同年 10 月満 州電業(株) 入社。1947 年 7 月東京商工局。同年 12 月日本発送電(株)入社。電力再編成で(財)電 力中央研究所技術研究所勤務。1964 年 4 月同所 電力第 2 部長兼塩原試験場長。1 1967 年 1 月京都 大学工学部教授。1982 年 4 月同名誉教授, 関西 電力(株)顧問, 捸南大学教授 (1990 年 3 '月退 職), 現在に至る。その間, 電力系統の計画, 運用, 系統絶縁設計, 同期機の定態および動的特性，高電圧工学などに属する研究に従事。 工学博士。日本学術会議会員 $(12,13,14$ 期, 第 5 部 $), 1991$ 年, 文 部省核融合科学研究所評議員。1979 年度電気学会会長。1956, 1976 年電気学会論文賞, 1962,1968 年同進歩賞, 1964 年同電力賞, 1981 年同功労賞, 1966 科学技術庁長官賞受賞。 